
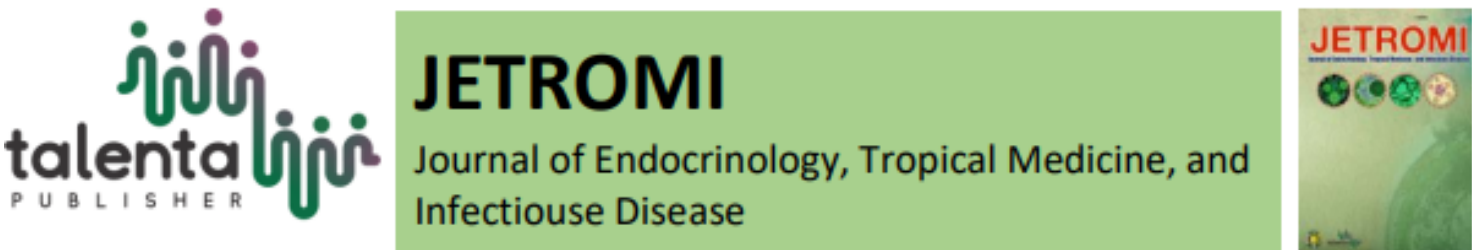

\title{
The Level of Handwashing Knowledge and Behavior of Yos Sudarso High School Medan Students' During The COVID-19 Pandemic
}

\author{
Cindy Elvira ${ }^{1}$, Causa Trisna Mariedina ${ }^{2}$ \\ ${ }^{1}$ Faculty of Medicine, Universitas Sumatera Utara, Medan, North Sumatera, Indonesia \\ ${ }^{2}$ Department of Pathology Anatomy, Faculty of Medicine, Universitas Sumatera Utara, Medan, \\ North Sumatera, Indonesia
}

\begin{abstract}
Background: The COVID-19 (Coronavirus Disease 2019) outbreak which was first detected in Wuhan, China, in December 2019, has spread rapidly. One way of preventing and controlling infection in the community is by washing hands thoroughly and regularly. The purpose of this study was to determine the level of handwashing knowledge and behavior of Yos Sudarso High School Medan students' during the COVID-19 pandemic. Method: The design used was one group pretest-posttest design. The type of data is primary data obtained through online questionnaires using a total sampling technique. Results: Of the 76 respondents, the level of knowledge on handwashing was dominated by the low category, namely 65 people (85.5\%) and the good category of handwashing behavior, namely 59 people (77.6\%). After being given information, the level of the good knowledge was 35 people (46.1\%) and the good behavior was 66 people (86.8\%). Students have a low knowledge about handwashing but have a good handwashing intensity behavior during the COVID-19 pandemic. Conclusion: Given information, there is an increase on the level of handwashing knowledge and behavior of Yos Sudarso High School Medan students' during the COVID-19 pandemic.
\end{abstract}

Keyword: COVID-19; Handwashing; Knowledge; Behavior; High School

\begin{abstract}
Abstrak. Latar belakang: Wabah COVID-19 (Coronavirus Disease 2019) pertama kali terdeteksi di Wuhan, Cina, pada Desember 2019, telah berkembang dengan cepat. Salah satu cara pencegahan dan pengendalian infeksi di masyarakat adalah mencuci tangan dengan teliti dan teratur. Tujuan dari penelitian ini adalah untuk mengetahui tingkat pengetahuan dan perilaku mencuci tangan siswa/i SMA Yos Sudarso Medan pada era pandemi COVID19. Metode:Desain yang digunakan adalah one group pretest-posttest design. Jenis data adalah data primer yang diperoleh melalui kuesioner online dengan teknik sampling berupa total sampling. Hasil: Dari 76 orang responden, tingkat pengetahuan mencuci tangan didominasi oleh kategori kurang yaitu 65 orang $(85,5 \%)$ dan perilaku mencuci tangan didominasi oleh kategori baik yaitu 59 orang $(77,6 \%)$. Setelah diberikan informasi, tingkat pengetahuan baik menjadi sebanyak 35 orang $(46,1 \%)$ dan perilaku baik sebanyak 66 orang $(86,8 \%)$. Siswa/i memiliki tingkat pengetahuan kurang tentang mencuci tangan yang baik dan benar namun memiliki perilaku intensitas mencuci tangan yang baik pada era pandemi COVID-19. Kesimpulan: Pemberian informasi, terdapat peningkatan terhadap tingkat
\end{abstract}

*Corresponding author at: Faculty of Medicine, Universitas Sumatera Utara, Medan, North Sumatera, Indonesia

E-mail address: cindyelviraa@gmail.com 
pengetahuan dan perilaku mencuci tangan siswa/i SMA Yos Sudarso Medan pada era pandemi COVID-19.

Kata Kunci: COVID-19; Mencuci Tangan; Pengetahuan; Perilaku; SMA

Received 30 January 2021 | Revised 27 February 2021 | Accepted 28 February 2021

\section{Introduction}

The COVID-19 (Coronavirus Disease-2019) outbreak which was first detected in Wuhan, China, in December 2019, has spread rapidly. On 30th January 2020, the Director-General of WHO stated that the current outbreak was a public health emergency of international concern. As of 12th March 2020, the COVID-19 outbreak has declared a pandemic [1]. Infection is susceptible to all ages and can be transmitted by droplets produced when coughing and sneezing in both symptomatic and asymptomatic patients and before the onset of symptoms. Infection is also acquired by touching a surface contaminated with the virus and then touch the nose, mouth, and eyes [2]. The best prevention for this outbreak is to avoid exposure to the virus. Infection Preventive and Control (IPC) can reduce the risk of exposure including wearing a face mask, covering coughs and sneezing with a tissue which is then discarded safely, washing hands thoroughly and regularly with soap or disinfection with hand sanitizers that contain at least $60 \%$ alcohol (if soap and water are unavailable), avoiding contact with infected persons, maintaining distance, and refraining from touching the eyes, nose, and mouth with unwashed hands [3]. The number of COVID-19 cases reported to WHO has increased since the first report of COVID-19 in December 2019 from the WHO China Country Office [4]. The city of Medan is one of the cities deemed red zone in Indonesia. On 15th April 2020, the city of Medan was the highest spread of the COVID-19 area in North Sumatera with the community condition that many did not comply with health protocol amidst the COVID-19 pandemic [5].

The increasing number of COVID-19 cases reported to WHO from day to day indicates the unbreaking chain of transmission. The level of knowledge about preventive behavior may play an important role in this. For this reason, one of the efforts to prevent the COVID-19 virus is to increase the knowledge and behavior of handwashing so that the spread of the virus can be controlled and break the chain of spread. Based on this background, researchers want to research the level of handwashing knowledge and behavior of Yos Sudarso High School Medan students' during the COVID-19 pandemic.

\section{Methodology}

This research method is quasi-experimental with one group pretest-posttest design. This research was conducted at Yos Sudarso High School Medan from July 2020 to December 2020. The subject of the study were high school students grade X, XI, XII with school years 2020/2021. The sampling method is total sampling with the inclusion criteria include: Yos Sudarso High School 
students grade X, XI, XII with school years 2020/2021 who were willing to participate in research. The study used instruments such as a questionnaire that had been validated and reliable. The questionnaires were given online through google form and were given twice to respondents which were before and after being given information (pretest and posttest).

\section{Result}

\subsection{Characteristics Data of Respondents}

The characteristics data of respondents can be seen in the table below:

Table 1 Data distribution of respondents

\begin{tabular}{llll}
\hline No & Data & Frequency & Accuracy (\%) \\
\hline & Grade & & \\
1 & X & 26 & 34.2 \\
2 & XI & 26 & 34.2 \\
3 & XII & 24 & 31.6 \\
\hline & Sex & & \\
4 & Male & 38 & 50 \\
5 & Female & 38 & 50 \\
\hline$\quad$ Source of & & \\
$\quad$ information & 39 & 51.3 \\
6 & Internet & 19 & 25 \\
7 & TV / Radio & 4 & 5.3 \\
8 & Health Workers & 14 & 18.4 \\
9 & Others & &
\end{tabular}

\subsection{Prevalence of Handwashing Knowledge and Behavior Before Being Given Information (Pretest)}

The prevalence of students' handwashing knowledge and behavior before being given information (pretest) can be seen in the table below:

Table 2 Prevalence of Knowledge and Behavior on Pretest

\begin{tabular}{llll}
\hline & Data & Frequency & Accuracy $(\%)$ \\
\hline & Level of & & \\
& Knowledge & & 3.9 \\
1 & Good & 3 & 10.5 \\
2 & Moderate & 8 & 85.5 \\
3 & Low & 65 & \\
\hline & Level of Behavior & & 77.6 \\
4 & Good & 59 & 22.4 \\
5 & Moderate & 17 & 0 \\
6 & Low & 0 & \\
\hline
\end{tabular}




\subsection{Prevalence of Handwashing Knowledge and Behavior After Being Given Information (Posttest)}

The prevalence of students' handwashing knowledge and behavior after being given information can be seen below:

Table 3 Prevalence of Knowledge and Behavior on Posttest

\begin{tabular}{llll}
\hline & & Frequency & Accuracy (\%) \\
\hline & Level of Knowledge & & \\
1 & Good & 35 & 46.1 \\
2 & Moderate & 20 & 26.3 \\
3 & Low & 21 & 27.6 \\
\hline & Level of Behavior & & \\
4 & Good & 66 & 86.8 \\
5 & Moderate & 10 & 13.2 \\
6 & Low & 0 & 0 \\
\hline
\end{tabular}

\section{Discussion}

The number of respondents collected was 76 people. Table 1 shows that respondents are evenly distributed in each grade with both male and female have an equal frequency. Respondents obtain information about handwashing during the COVID-19 pandemic mostly from the internet (51.3\%). By the characteristics of curious teenagers, the large number of media that provide information make teenagers easier to access various information, including through mass media such as magazines, tabloids, newspapers, and so on, as well as electronic media such as televisions, radios, and the internet [6]. Knowledge means everything that is known regarding matters or education [7]. Table 2 shows that the majority of respondents have a low level of knowledge on handwashing during the COVID-19 pandemic, namely 65 people (85.5\%) which means the majority of the respondents in this study know very little about washing hands, including the duration, equipment for handwashing during the COVID-19 pandemic, and procedures or how to wash hands properly. A study conducted on Vietnamese people showed that only $42.8 \%$ of respondents could state the steps of handwashing properly [8]. According to Notoatmodjo, knowledge can be influenced by various factors, such as education, information, work, experience, beliefs, and socio-culture [9]. Human behavior is influenced by a variety of human characteristics, including intelligence level, emotional level, gender, and so on. Another factor such as environmental factors also has a big impact on human behavior [10]. Table 2 shows that majority of respondents have a good level of behavior on handwashing during the COVID19 pandemic, namely 59 people $(77.6 \%)$ which means the majority of the respondents in this study have a good handwashing intensity behavior during the COVID-19 pandemic. A study conducted at Pasar Sukaramai Medan showed that the majority of the respondents did not have a good intensity on handwashing (73.33) [11]. The result which contradicts this study can be caused by the environmental factor and supporting factor such as the availability of facilities for 
handwashing. After the respondents filled out the questionnaires (pretest), respondents are being given information about the proper and correct way of handwashing through social media with a poster and video presentations. One week after being given information, respondents were asked to fill out the questionnaires again (posttest) to determine the handwashing knowledge and behavior after being given information. Table 3 shows that after being given information, there is an increase in the level of handwashing knowledge and behavior during the COVID-19 pandemic. The majority of respondents have a good level of knowledge on handwashing, namely 35 people (46.1\%), and have a good level of behavior on handwashing, namely 66 people (77\%). Hand hygiene is one of the effective ways that can be taken to reduce the spread of pathogens and prevent infections, including the COVID-19 virus [12]. Apart from the importance of intensity for frequent handwashing, it is important to do it the right way, applying it according to the correct procedure and time. Several recommendations from WHO and UNICEF show how, when, and the duration of handwashing to reduce the spread of SARS-CoV-2 and to reduce the risk of other infections [13].

\section{Conclusion}

Students have low knowledge about the proper and right way of handwashing but have a good handwashing intensity behavior during the COVID-19 pandemic. After being given information, there is an increase in the level of handwashing knowledge and behavior of Yos Sudarso High School Medan students' during the COVID-19 pandemic.

\section{REFERENCES}

[1] World Health Organizations, "Preparedness, prevention and control of COVID-19 in prisons and other places of detention," WHO Regional Office for Europe, 2020. [Online]. Available at: https://www.euro.who.int/en. [Accessed: Apr. 20, 2020].

[2] Singhal. T, "A review of the coronavirus disease-2019," Indian J Pediatr, vol. 87, pp. 281286. 2020.

[3] S. P. Adhikari, S. Meng, Y. J. Wu, Y. P. Mao, R. X. Ye, Q. Z, Wang, C. Sun, S. Sylvia, S. Rozelle, H. Raat, and H. Zhou, "Epidemiology, causes, clinical manifestation and diagnosis, prevention and control of coronavirus disease (COVID-19) during the early outbreak period: a scoping review," Infectious diseases of poverty, vol. 9, no. 1, pp. 1-12. 2020.

[4] D. G. Ahn, H. J. Shin, M. H. Kim, S. Lee, H. S. Kim, J. Myoung, B. T. Kim, and S. J. Kim, "Current status of epidemiology, diagnosis, therapeutics, and vaccines for novel coronavirus diesease 2019 (COVID-19)," Journal of Microbiology and Biotechnology, vol. 30, no. 3, pp. 313-324. 2020.

[5] Pemprov Sumut, "Situasi COVID-19 di Sumatera Utara," Pemerintah Provinsi Sumatera Utara, 2020. [Online]. Available at: http://covid19.sumutprov.go.id/. [Accessed: Apr. 28, 2020].

[6] Nana Syaodih Sukmadinata, "Landasan Psikologi Proses Pendidikan," Bandung: PT Rosdakarya. 2005.

[7] KBBI, "Pengertian Pengetahuan," Badan Pengembangan dan Pembinaan Bahasa, 2016. [Online]. Available at: https://kbbi.kemdikbud.go.id/entri/pengetahuan. [Accessed: Apr. 25, 2020].

[8] L. T. Le Thi Thanh Huong, T. T. T. H. Hoang, N. T. H. Nguyen Quynh Anh, and B. T. T. Do Man Cuong, "Reported handwashing practices of Vietnamese people during the COVID- 
19 pandemic and associated factors: a 2020 online survey," AIMS public health, Vol. 7, No. 3, p. 650.2020.

[9] Notoatmodjo, "Promosi Kesehatan Teori dan Aplikasi," Jakarta: PT Rineka Cipta. 2010.

[10] Pranadji, Diah K, "Perencanaan Menu Untuk Penderita Diabetes Mellitus", Jakarta: Penebar Swadaya. 2000.

[11] H. E. Siahaineinia, and T. L. Bakara, "Persepsi Masyarakat Tentang Penggunaan Masker dan Cuci Tangan Selama Pandemi COVID-19 di Pasar Sukaramai Medan," Wahana Inovasi: Jurnal Penelitian dan Pengabdian Masyarakat UISU, Vol. 9, No. 1, pp. 172-176. 2020.

[12] World Health Organization, "WHO Save Lives: Clean Your Hands In the Context of COVID-19," May. 20, 2020. [Online]. Available at: https://www.who.int/campaigns/savelives-clean-your-hands. [Accessed: May. 25, 2020].

[13] D. Guzek, D. Skolmowska, and D. Glabska, "Analysis of gender-dependent personal protective behaviors in a national sample: Polish Adolescents COVID-19 Experience (PLACE-19) study," International journal of environmental research and public health, Vol. 17, No. 16, p. 5770. 2020. 